\title{
Perspectives in oil and gas supply chain management
}

\author{
Shatina Saad ${ }^{1, *}$, Zulkifli Mohamed Udin², Norlena Hasnan ${ }^{3}$ \\ ${ }^{1}$ Faculty of Business Management, University Technology MARA, 42300 Bandar Puncak Alam, Selangor, Malaysia \\ ${ }^{2}$ School of Technology Management and Logistic, Universiti Utara Malaysia, 06010 Sintok, Kedah, Malaysia \\ ${ }^{3}$ UUM College of Business, Universiti Utara Malaysia Kuala Lumpur Campus, 50300 Kuala Lumpur, Malaysia \\ Email address: \\ shatinas@salam.uitm.edu.my (S. Saad), zulkifli@uum.edu.my (Z. M. Udin), norlena@uum.edu.my (N. Hasnan)
}

\section{To cite this article:}

Shatina Saad, Zulkifli Mohamed Udin, Norlena Hasnan. Perspectives in Oil and Gas Supply Chain Management. International Journal of Business and Economics Research. Special Issue: Supply Chain Management: Its Theory and Applications. Vol. 3, No. 6-1, 2014, pp. 45-50. doi: 10.11648/j.ijber.s.2014030601.17

\begin{abstract}
In this globalization era, petroleum companies are one of the dynamic supply chain entities, which require a dynamic process of capabilities. Companies may encounter problems related to the dynamic process in firm's capabilities. Such dynamic process requires simultaneous acquisition and continuous re-evaluation of partners, technologies and organizational structures. However, the more flexible the firms deal with the problems in their engagement of stakeholders, the more likely for them to explore, create, and invest in the dynamic capabilities, hence higher performance level over time. Therefore, due to their high degree of uncertainties circulate through the supply chain network; as a result, petroleum companies require dynamic supply chain capabilities. Motivated by the complexity of uncertainty in the petroleum companies and its typical characteristic of the supply chain, this study intends to understand the perspective of dynamic supply chain management focusing on the learning orientation. This study employs interpretive paradigm where it will guide towards rigor qualitative methodology. This study also provides rich and thick description of the dynamic supply chain capabilities where the outcome will contribute to the managerial and theoretical perspective of supply chain management in oil and gas industry.
\end{abstract}

Keywords: Dynamic Capabilities, Supply Chain Management, Qualitative Research, Oil and Gas

\section{Introduction}

Supply chain management (SCM) has received in recent years a great deal of attention by researchers and practitioners. Effective SCM will lead to a lowering of the total amount of resources required to provide the necessary level of customer service to a specific segment and improving customer service through increased product availability and reduced order cycle time [1]; engage in information exchange (forecasting techniques, inventory management, delivery) and structural collaboration (just-in-time system, outsourcing, vendor-managed inventory and co-locating plants) [2, 3]; relationships with downstream supply chain partners to create end-customer value [4] and maximize benefits and minimize costs along the supply chain [5]. Thus, the nature of SCM becomes visible to participating companies with successful implementation in the ever-changing global environment of the business world; risks abound, and it greatly affects the decision-making processes of the business management.

According to [6], a supply chain is a dynamic process and involves the constant flow of information, materials, and funds across multiple functional areas both within and between chain members. Members in the chain need to cooperate with their business partners in order to meet customer's needs and to maximize their profit. However, it is a very difficult task in managing the multiple collaborations in a supply chain because there are so many firms involved in the supply chain operations with its own resources and objectives. The interdependence of multistage processes also requires real-time operation and decision making across different tasks, functional areas, and organizational boundaries in order to deal with problems and uncertainties [7]. The strategic move of focus for mass customization, quick response, and high quality service cannot be achieved without more complex cooperation and dynamic structure of supply chains.

Reference [8] identified a dynamic collaboration capability should help a company access, shift and leverage supply chain resources to rapidly respond to a changing competitive environment. A dynamic process also involves the simultaneous acquisition and continuous re-evaluation of 
partners, technologies, and organizational structures. Firms may encounter the same problems, but they may have different awareness and potential solutions due to differences in their engagement of stakeholders. The more flexible and open of the firms to the issues there is more likely for them to explore, create, and invest in the dynamic capabilities $[9,10]$. Therefore, firms that possess a dynamic collaboration capability should be able to sustain high performance levels over time.

Environmental uncertainties in oil and gas industry lead to a need for higher reliability and flexibility within the production systems and the planning and control systems in the supply chain. Reducing these uncertainties will be achieved by understanding the root causes and how they interact with each other. Changes in markets, products, technology, and competitors are occurring at an increasingly rapid pace $[4,11]$. As a result, managers must take decisions on shorter notice, with less information, and with higher penalty costs. Therefore, a reliable yet a flexible system are fundamentally needed to assist the management in making decisions that might prove to be the make-or-break decision for their companies. Therefore, a dynamic supply chain is identified.

\section{Literature Review}

Petroleum companies, also known as oil and gas companies have formed a key part of the global economy for the last decade since petroleum or crude oil has become the main fuel source. By 2020, Malaysia will have a more diversified oil, gas and energy sector that remains vital to the nation development, and that builds on the nation's competitive advantages. A key thrust not only to intensify exploration and enhance production from domestic reserves but also to develop a strong regional oil field services and equipment hub and a stronger presence in the regional midstream logistics and downstream markets [12]. Malaysia's national oil \& gas Company, Petroleam Nasional Berhad (PETRONAS), holds exclusive ownership rights to all oil \& gas exploration and production project in Malaysia. As Malaysia's oil fields are maturing, the government is focused on enhancing output from existing fields and from new offshore developments of both oil \& gas, which are expected to increase aggregate production capacity in the near- to mid-term [13]. Among other major players in Malaysia's oil \& gas industry are Esso Malaysia Berhad and Shell Malaysia Limited.

Reference [14] stated that, a typical petroleum industry supply chain was composed of an exploration phase at the wellhead, crude procurement and storage logistics, transportation to the oil refineries, refinery operations, and distribution and transportation of the final products. As it can be seen in Figure 1, the upstream activities (exploration, development and production of crude oil or natural gas) and downstream activities (tankers, pipelines, retailers and consumers) are two important activities in the petroleum industry [15]. Supply chain management in oil \& gas industry requires the company to integrate its decisions with those made within its chain of customers and suppliers. This process involves relationship management by the company with their customers and suppliers. A firm can create long-term strategic relationships with their suppliers and in most cases, there is a collaboration process between the oil and gas company with its suppliers [5]. Generally, oil \& gas companies view their supply chain configuration and coordination systems as worthy of improvement. Making necessary improvements over time allows the firm to gain competitive advantages in the marketplace.

The motivation of this study is to understand the environment of the dynamic supply chain in Malaysia's oil \& gas industry by looking into the dynamic supply chain capabilities. Oil \& gas span a large spectrum in a supply chain, from the strategic to the tactical to the operational level and over various functions in the supply chain network, from purchasing of the raw materials through the manufacturing to the distribution and sales [7, 14, 16]. Integrated and coordinated decision making across diverse geographically distributed refinery manufacturing and storage sites also offer the additional challenge the overall oil \& gas supply chain. While manufacturing facility's management is an integral part of the chain, transportation logistics and finished product distribution management remains essential elements of the oil $\&$ gas supplies chain. Therefore, this study is to identify and understand the dynamic supply chain capabilities perspectives of oil \& gas industry in Malaysia's practices. Specifically, the dynamic supply chain's capabilities will be discussed in this study are the firm's capabilities focusing at the learning orientation of oil \& gas industry.

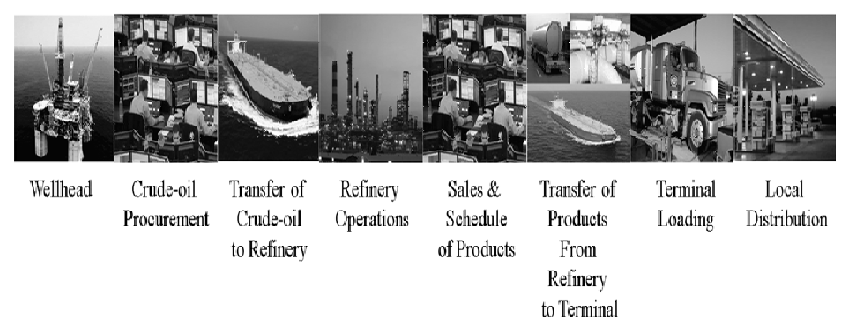

Figure 1. Supply Chain of Oil and Gas Industry.

\section{Methodology}

\subsection{Data Collection}

This study will be focusing on exploring issues on dynamic supply chain capabilities on oil \& gas industry only, thus the generalization cannot be done in other organizations and industry throughout Malaysia. The assumption of this study is that the major players in the oil \& gas industry are doing the similar practices in managing their supply chain. In the exploration and production sectors of the oil and gas industry, the product is exactly the same for all competing firms with very narrow product differentiation. Inquiry participants were identified from Malaysia Oil \& Gas Service Council (MOGSC) members. The interviews guide developed for the in-depth interviews were based on the research question and literature.

From the snowballing technique engaged in getting the informants, a total of four service contractors were 
interviewed. All of them are from headquarters office in Kuala Lumpur and surroundings. The interviews were conducted at a time and place of the informant's preferences. Two interviews were done at the informant's offices, and another two at a restaurant bistro. All interviews were tape-recorded and later transcribed verbatim. All four interviews were conducted in English and Bahasa Malaysia. The transcribed interview in Bahasa Malaysia was translated into English and was double checked for accuracy by the bilingual researchers.

\subsection{Data Analysis}

The database for the analysis consists of the interviews verbatim transcription. Interview data were analyzed using the constant comparative method of data analysis [17, 18]. This method consists of first open-coding from each interview transcript for relevant data responsive to the study's research questions. These coded segments later are combined through axial coding into themes/categories that are explanatory of the phenomenon. The same process is undertaken with the transcript of the second interview. Themes/categories from the additional transcript are compared with the first transcript and one set of themes/categories is derived from the two interviews. This process continues through following interviews. The final sets of themes/categories are the findings of the study. These findings are in turn supported by quotes from the transcripts. These quotes are the evidence for the findings [17].

In qualitative research, data analysis is best done in tandem with data collection. The researcher or interviewer informally debriefed after each interview and informally compared respondents' perspectives as collecting data. Concurrent data analysis allows for theoretical sampling to take place and allows for checking for internal validity by representing participants' perspectives and understandings as the researcher check the emerging understanding with participants. Data collection was concluded after the four interviews as the data were saturated; where, no new insights were imminent in the final interviews.

\subsection{Ethical Consideration}

Prior to the interview, participants were informed of the research objective and the interview process, and rest assured of their anonymity and the confidentiality of their responses. Pseudonyms are used in this paper. Written consent was obtained from participating informants. Participants were presented with a copy of consent letter and appreciation acknowledging their participation.

\subsection{Study Limitation}

In qualitative research, generalizability is not possible in the statistical sense. Rather, qualitative research is designed to understand and describe the phenomenon from the perspective of the participants. The findings of a qualitative study are supported by the evidence gleaned from the interviews, and it is up to the reader of the study to determine the applicability of the findings to their situation.

\section{Findings}

Data were obtained from four service contractors of oil \& gas industry players as can be seen in Table 1.

All respondents were service contractors who are registered with a valid license and allowed to supply goods/services to both the upstream sector of the oil \& gas industry in Malaysia and the downstream activities of PETRONAS, including maritime activities. The motives can be grouped into four themes: (1) commitment to learning, (2) shared vision, (3) open mindedness, and (4) intra-organizational knowledge sharing, in oil \& gas dynamic supply chain capabilities. The following details the motives.

\subsection{Commitment to Learning}

The informants reported that commitment to learning is important as firm's capabilities of the dynamic supply chain capabilities in oil and gas industry. In Mr. One's organization case, it was then stated in the vision of the organization. The vision stated as "We are committed to nurturing our people who make us great, never compromising on their well being at all times."

For Mrs. Weda, a businesswoman in men dominated field, even though with a small team members, she emphasized her ten permanent staff and the free lancers to gain new insight and learn from others. For example, she encourages her staff to further studies in their own preference and supports them morally to upgrade their qualification. Mrs. Weda also completed her MBA as part-time in one of the public universities, and she believes that everyone should learn new things every day.

\subsection{Shared Vision}

Shared vision in oil \& gas supply chain players goes beyond. The informants reported that supply chain was really complex, structured and governed by PETRONAS and other stakeholders.

Mrs. Weda declared the company vision, mission and values were been shared among the staff. The company vision commitment is to provide an innovative, quality and cost effective solutions to their clients. As she said the mission is "We aspire to provide innovative, efficient and cost effective pipeline inspection and niche maintenance solutions to the oil and gas industry without compromising quality and health, safety and environment."

For Mr. One, the company emphasized "The values shared are Passion to Excel, Responsible at Work, Integrity - the Power of Trust, Dedicated to our Customers' Success and Enterprising as a Team." Since the company vision is to become "A Leading Marine and Heavy Engineering Organization of Choice," their mission is to be a high performance company that delivers engineering solutions to help their customers stay ahead.

Differently with Mr. Man, the company vision is to become a competent and reliable contractor and supplier. As Mr. Man mentioned, "Even though the company considered newly registered, but we are an old player in the services 
industry and intentionally being a recognize contractor. We did fabricate our own product for our client." Boosting up the confidence in the market is the prime necessity.

And finally, in Mr. Jay Company, quick supports are firmly ensured. They strive to be the source of choice, offering high integrity technical support, excellent quality products and exceptional customer's satisfaction.

Table 1. Profile of Participants

\begin{tabular}{|c|c|c|c|c|c|}
\hline No & Name $^{+}$ & Designation & Year in Services & Case Description & Location \\
\hline 1 & Mrs. Weda & Managing Director & 20 years & $\begin{array}{l}\text { Malaysian company and operationally } \\
\text { commenced business in } 2008 \text {. It aims is to } \\
\text { supply state of the art and niche equipment and } \\
\text { specialized services for oil \& gas industry, } \\
\text { especially for pipeline either to the downstream } \\
\text { or upstream sector. }\end{array}$ & Headquarters - Kuala Lumpur \\
\hline 2 & Mr. One & $\begin{array}{l}\text { Group General } \\
\text { Manager }\end{array}$ & 35 years & $\begin{array}{l}\text { This company is a leading offshore and marine } \\
\text { services' provider in Malaysia, focused primarily } \\
\text { on the oil \& gas sector. It offers a wide spectrum } \\
\text { of offshore construction, offshore conversion } \\
\text { and marine repair services at two yards in Johor. } \\
\text { Over the span of } 40 \text { years, the company has } \\
\text { grown organically while enhancing its } \\
\text { capabilities and service offering through } \\
\text { strategic partnerships with global leaders. } \\
\text { This company was incorporated as a Private }\end{array}$ & $\begin{array}{l}\text { Headquarters - Kuala Lumpur } \\
\text { Fabrication - Johor }\end{array}$ \\
\hline 3 & Mr. Man & Managing Director & 30 years & $\begin{array}{l}\text { Limited Company in } 2010 \text {. The company aims to } \\
\text { involve in the business of providing high quality } \\
\text { services for the oil \& gas industry, locally and } \\
\text { globally. It is focusing on fabrication and rental } \\
\text { of "weld safe habitat." }\end{array}$ & $\begin{array}{l}\text { Headquarters - Kuala Lumpur } \\
\text { Fabrication - Terengganu }\end{array}$ \\
\hline 4 & Mr. Jay & Managing Director & 20 years & $\begin{array}{l}\text { This company was } 100 \% \text { local status company, } \\
\text { was founded by a team that has collectively } 20 \\
\text { years experience in engineering industries. It } \\
\text { delivers products and services exactly as the } \\
\text { industry needs, if not better. Specializing in oil \& } \\
\text { gas industry, with expertise in the zone rated } \\
\text { hazardous area equipment, and the main goal is } \\
\text { to provide solutions for their clients' } \\
\text { requirement. }\end{array}$ & Headquarters - Kuala Lumpur \\
\hline
\end{tabular}

+ All the names are pseudonyms.

\subsection{Open-Mindedness}

Another frequently stated reason of firm's capabilities was the open-mindedness of the service contractors. All service contractors will be invited for the tendering process and given fair chance to submit a tender of a project proposal before being awarded.

Mrs. Weda reported that 'Even same service I didn't go marketing, but I still received invitation. End of the day who will get the preferences is those who met the technical requirement and commit approval."

"The company strives continuously improve the management of supply chain processes to ensure that the Company is operating responsibly at all times. Our vendors and subcontractors play a crucial part in contributing to the Company's success. We value our vendors and subcontractors as partners in our business. To enhance the relationship with our partners' number of initiatives was implemented throughout the year." Mr. One reported the company seriously appreciated their vendors and subcontractors to share their opinions and views. The suggestions were taken into consideration for further continuous improvement.

\subsection{Intra-Organizational Knowledge Sharing}

Evidence from the study shows that intra-organizational knowledge sharing happening in the oil \& gas supply chain. Several informants reported that they attended training by PETRONAS and later share the information with their staff. Mr. Man believes that to broaden their capabilities and competencies in today competitive market, partnership and joint venture effort is the key to achieve and enhance their scope of business.

According to Mr. One, in order to ensure the partnership can be sustained; the company's SCM division successfully organized a Contractors Dialogue Day. "It was attended by 53 selected companies operating in offshore, marine repair, yard optimization and administrative services. During this occasion, the contractors were briefed on their key performance index (KPI) evaluation and assessment as well as the process flow of the vendors' improvement initiative. We invited four contractors to share their views on the innovative actions/strategies that they had implemented and how the contractor community would support us through the transformation journey." Subsequent from the event, the 
company also hosted its Vendor Dialogue. The 219 high performing suppliers and contractors who participated were updated on the Company's transformation initiatives to deliver engineering, procurement and construction (EPC) projects on time and at cost, as well as to strengthen and develop strategic partnerships between the Company and its vendor's community.

There were informants who reported partnering with foreign companies. Mrs. Weda was one of them: "We are lucky since we are small. This is possible with the key management personnel that accumulated years of experience in oil \& gas. We also have strategic and reputable foreign and local principals and technology partners. Ultimately, we target to localize the foreign technology and customized our services to suit clients' requirement."

\section{Discussion}

Findings from the study will be discussed according to the motives identified: (1) commitment to learning, (2) shared vision, (3) open mindedness, and (4) intra-organizational knowledge sharing, in oil \& gas dynamic supply chain capabilities.

By society, Malaysian's oil \& gas players are dominated by those who have technical and engineering discipline. This is due to in oil \& gas industry; it requires someone that possesses and understands very technical documents to make a decision. However, in the dynamic supply chain capabilities, the learning orientation as firm's capabilities cannot be ignored. Commitment to learn for everyone in the chain to improve is pretty much encouraged. Due to robust of technology in oil \& gas industry, everyone in the chain needs to be par with the technology advances. They can gain new insight by attending courses or any exhibition organized within or outside the country.

Since oil \& gas industry in Malaysia is governed and monitored by PETRONAS, the service contractors also have to share the similar vision throughout the supply chain. This is to ensure that everyone in the chain understands that small mistakes can create nation issues. A small mistake during the service installation can affect the whole chain and tarnish the image of the company and the nation in the global market. Therefore, understanding of the shared vision needs to be inculcating to everyone in the supply chain.

The firm's capabilities also identified open-mindedness as one of the dynamic supply chain capabilities. Most of the oil \& gas players know each other's since they have been in the industry for so long. All contractors registered with licensed were invited for the new or existing project tendering process. Although they know each other, the awards of a project are only being given to those who meet the required specification as approved by the technical committee. Everyone in the oil \& gas supply chain instill the high level values of professionalism and integrity during the processes.

Finally, oil \& gas industry also emphasize the intra-organizational knowledge sharing among the supply chain. Sharing experience and expertise throughout the chain emerged results and consequently, new insights and knowledge to the dynamic supply chain capabilities. The study suggests that well-planned and structured supply chain will reduce the uncertainties in the dynamic supply chain capabilities. Thus, the oil \& gas firms need to ensure that people in the chain acquire all capabilities in learning orientation.

\section{Conclusion and Implications}

Evidence from this study suggests that firm's capabilities comprise of commitment to learning, shared vision, open-mindedness and intra-organizational knowledge sharing. For oil \& gas supply chain players they need to understand what are dynamic supply chain capabilities. The service contractors are restricted and controlled by the PETRONAS procedures and requirement.

Reference [19] identified that dynamic capabilities arise from learning and comprise the firm's methods for modifying existing operating routines. Learning orientation is needed to develop dynamic supply chain capabilities that continuously re-tooling the obsolete cross-organizational capabilities and develop novel capabilities.

Meanwhile, supported by another study [20] defined learning orientation as the set of organizational values that influence the tendency of the firm to create and use knowledge. It is observed by a set of knowledge-questioning norms, including commitment to learning, open mindedness, and shared vision. Therefore, learning orientation influences what kind of information is gathered and how it is interpreted, evaluated, and shared [21].

Moreover, in the intra-organizational knowledge sharing, the firm need to do further initiatives in order to sustain their organizational competitiveness. Another reference [22] highlighted that learning orientation firms recognize the risks associated with knowledge imbalance between supply chain members leading to instability in supply chain relationships. This will limit to the learning capacity of any single firm because of the difficulty in transferring tacit knowledge between organizations. This recognition breeds the desire to understand the supply chain partner's distinctive existing capabilities, instead of pursuing a costly, and potentially ineffective, strategy of attempting to imitate the partner's tacitly held capabilities.

In a summary, studies on dynamic supply chain capabilities of oil \& gas industry identified in several elements of firm's capabilities such as commitment to learning, shared vision, open-mindedness and intra-organizational knowledge sharing. This study integrates the firm's capabilities as they are considered crucial in ensuring the dynamic supply chain capabilities are well practiced. Trust and supplier's relationship plays a major role in the firm's capabilities. The environmental uncertainty influence to build dynamic supply chain capabilities as it modifies dynamic supply chain performance and leading to any competitive advantage in the oil \& gas industry in Malaysia. 


\section{Acknowledgement}

The authors would like to thank gratefully Ministry of Education, Malaysia for funding this research under the Public University Academic Training Scheme (SLAI) and acknowledge valuable comments from the anonymous reviewers, which greatly improved this paper.

\section{References}

[1] R. Banomyong and N. Supatn,(2011), "Developing a supply chain performance tool for SMEs in Thailand," Supply Chain Management: An International Journal, Vol. 16, No. 1,pp. 20-31.

[2] H. C. Co and F. Barro,(2009), "Stakeholder theory and dynamics in supply chain collaboration," International Journal of Operations \& Production Management, Vol. 29, No. 6,pp. 591-611.

[3] M. Raja Mazlan, R. and K. N. Ali,(2006), "Relationship between supply chain management and outsourcing."

[4] K. N. S. Iyer,(2011), "Demand chain collaboration and operational performance: role of IT analytic capability and environmental uncertainty," Journal of Business \& Industrial Marketing, Vol. 26, No. 2,pp. 81-91.

[5] C. M. Chima,(2007), "Supply-Chain Management Issues In The Oil And Gas Industry," Journal of Business \& Economics Research, Vol. 5, No. 6,pp. 27-36.

[6] V. Jain, S. Wadhwa, and S. G. Deshmukh,(2009), "Select supplier-related issues in modelling a dynamic supply chain: potential, challenges and direction for future research," International Journal of Production Research, Vol. 47, No. 11,pp. 3013-3039.

[7] S. Saad, Z. M. Udin, and N. Hasnan,(2014), "Dynamic supply chain capabilities: A case study in oil and gas industry," International Journal of Supply Chain Management, Vol. 3, No. 2,pp. 70-76.

[8] D. J. Teece, G. Pisano, and A. Shuen,(1997), "Dynamic capabilities and strategic management," Strategic Management Journal, Vol. 18, No. 7,pp. 509-533.

[9] V. Jain, S. Wadhwa, and S. G. Deshmukh,(2009), "Revisiting information systems to support a dynamic supply chain: issues and perspectives," Production Planning \& Control, Vol. 20, No. 1,pp. 17-29.

[10] S. L. Hart and G. Dowell,(2011), "Invited Editorial: A
Natural-Resource-Based View of the Firm : Fifteen Years After," Journal of Management, Vol. 37, No. 5,pp. 1464-1479.

[11] C. C. Defee and B. S. Fugate,(2010), "Changing perspective of capabilities in the dynamic supply chain era " The International Journal of Logistics Management, Vol. 21, No. 2,pp. 180-206.

[12] Performance Management and Delivery Unit, "Economic Transformation Handbook: A roadmap for Malaysia," 2010.

[13] Energy Information Administration. (December 2010, 1 February 2011). Malaysia energy data, statistics and analysis oil, gas, electricity, coal. Available: www.eia.doe.gov/cabs/malaysia/oil.html

[14] N. K. Shah, Z. Li, and M. G. Ierapetritou,(2011), "Petroleum refining operations: key issues, advances, and opportunities," Industrial and Engineering Chemistry Research, Vol. 50, No. pp. 1161-1170.

[15] N. M. Ali, "Sustainability of petroleum and environmental control in the Malaysian petroleum law," 2010.

[16] S. S. Pitty, W. Li, A. Adhitya, R. Srinivasan, and I. A. Karimi,(2008), "Decision support for integrated refinery supply chains: Part 1. Dynamic simulation," Computers \& Chemical Engineering, Vol. 32, No. 11,pp. 2767-2786.

[17] M. Muhamad, S. Merriam, and N. Suhami,(2012), "Why breast cancer patients seek traditional healers," International Journal of Breast Cancer, 689168,pp. 1-9.

[18] S. B. Merriam,(2009), Qualitative Research: A Guide to Design and Implementation. San Francisco, Calif,USA: Jossey-Bass/Wiley.

[19] M. Zollo and S. G. Winter,(2002), "Deliberate learning and the evolution of dynamic capabilities," Organization science, pp. 339-351.

[20] J. M. Sinkula, W. E. Baker, and T. Noordewier,(1997), "A framework for market-based organizational learning: linking values, knowledge, and behavior," Journal of the academy of marketing science, Vol. 25, No. 4,pp. 305-318.

[21] R. J. Calantone, S. T. Cavusgil, and Y. Zhao,(2002), "Learning orientation, firm innovation capability, and firm performance," Industrial marketing management, Vol. 31, No. 6,pp. 515-524.

[22] S. A. Zahra, H. J. Sapienza, and P. Davidsson,(2006), "Entrepreneurship and Dynamic Capabilities: A Review, Model and Research Agenda," Journal of Management Studies, Vol. 43, No. 4,pp. 917-955. 